\title{
Motion - Pancreatic endoscopy is useful for the pain of chronic pancreatitis: Arguments against the motion
}

\author{
Darwin L Conwell MD
}

DL Conwell. Motion - Pancreatic endoscopy is useful for the pain of chronic pancreatitis: Arguments against the motion. Can J Gastroenterol 2003;17(1):61-63.

Endoscopic therapy can be used to dilate strictures in the pancreatic duct, remove stones and drain pseudocysts. In addition, it provides an alternative to surgery for the management of pain in patients with chronic pancreatitis. Pain is a difficult problem in these patients, especially if substance abuse is present, and its medical management is generally unsatisfactory. The concept that pancreatic pain is related to increased pressure in the main pancreatic duct is unproven, and is not supported by the results of surgical intervention. Although pancreatic stenting is often technically successful at achieving drainage of the pancreatic duct and relieving pain over the short term, pain usually recurs with time, complications are frequent, and repeated stent changes are usually necessary. Pancreatic pseudocysts can be drained endoscopically, using transpapillary, cystogastrostomy or cystoduodenostomy approaches, but success rates are less than $50 \%$ and bleeding is a major complication. Pseudocysts should not be drained unless they are symptomatic, causing complications or enlarging. There have been no published studies comparing endoscopic with surgical or radiological modalities. Endoscopic therapy of pancreatic disorders is a new and interesting technique, but initial promising results need to be confirmed in large, well-designed clinical trials. Such studies would need to enrol large numbers of patients, and involve measurement of technical success, pain severity and quality of life parameters. At present, endoscopic techniques must be considered experimental.

Key Words: Chronic pancreatitis; Endoscopy; Pain
L'endoscopie pancréatique permet de soulager la douleur causée par la pancréatite chronique : Arguments contre cette proposition

RÉSUMÉ : L'endoscopie peut servir à dilater les sténoses du canal pancréatique, à retirer des calculs et à drainer des pseudokystes. De plus, elle offre une solution de rechange à la chirurgie pour le soulagement de la douleur chez les patients souffrant d'une pancréatite chronique. En effet, la douleur pose problème chez ces patients, surtout s'il y abus d'alcool ou de drogues, et le traitement médical en général est décevant. Rien, y compris les résultats de la chirurgie, n'étaye jusqu'à maintenant le concept selon lequel la douleur est liée à une augmentation de la pression dans le canal de Wirsung. Même si la pose de prothèses permet, sur le plan technique, de drainer le canal pancréatique et de soulager la douleur à court terme, celle-ci réapparaît avec le temps, les complications ne sont pas rares et, souvent, il faut remplacer les prothèses. Certes, l'endoscopie par voie transpapillaire, la cystogastrostomie et la cystoduodénostomie peuvent servir au drainage des pseudokystes pancréatiques, mais le taux de réussite est inférieur à $50 \%$ et les hémorragies en constituent une complication importante. On devrait s'abstenir de drainer les pseudokystes à moins que ceux-ci se montrent symptomatiques, c'est-à-dire causent des complications ou de la distension. Il n'existe pas de données publiées comparant l'endoscopie à la chirurgie et à la radiologie. Le recours à l'endoscopie pour le traitement des troubles du pancréas est à la fois nouveau et prometteur, mais les premiers résultats encourageants doivent être confirmés dans le cadre d'essais cliniques de grande taille, bien conçus. Pour ce faire, il faudrait trouver un grand nombre de patients et évaluer la réussite technique, l'intensité de la douleur et la qualité de vie. Aussi les techniques endoscopiques doivent-elles être considérées, à l'heure actuelle, comme expérimentales.
$\mathrm{E}_{\mathrm{b}}^{\mathrm{n}}$ ndoscopic therapy for biliary and pancreatic disease has become an exciting field with the advent of therapeutic endoscopy. The advances in biliary endoscopy have encouraged skilled endoscopists to turn their attention to pancreatic diseases. Endoscopic therapy is now available for the treatment of patients with acute and chronic pancreatitis and pancreas divisum. The history of endoscopic therapy for chronic pancreatitis can be summarized as follows:

- 1976 - Endoscopic sphincterotomy

- 1980 - Cystoduodenostomy

- 1981 - Biliary stenting for chronic pancreatitis

- 1983 - Cystogastrostomy

- 1985 - Pancreatic stenting
- 1987 - Extracorporeal shockwave lithotripsy for pancreatic stones

- 1989 - Expandable metal stents

The major indication for endoscopic therapy in chronic pancreatic disease is to provide an alternative to surgical intervention. It can treat complications, such as obstructive jaundice and pseudocysts, and can provide drainage of the main pancreatic duct in cases of lithiasis or stricture formation.

Chronic pancreatitis results in more than 122,000 outpatient visits and more than 56,000 hospitalizations each year in the United States (1). Alcoholism accounts for more than $70 \%$ of cases. Most of the admissions to hospital are

This article was originally presented at a symposium entitled, "Controversies in Gastroenterology", sponsored by Axcam Pharma, Toronto, Ontario, April 8 to 10, 2002

Department of Gastroenterology, Cleveland Clinic, Cleveland, Ohio 44195 USA

Correspondence: Dr DL Conwell, Department of Gastroenterology, Cleveland Clinic, 9500 Euclid Avenue, Desk S-40, Cleveland, Ohio 44195, USA. Telephone 216-444-6226, fax 216-444-6284, e-mail conweld@ccf.org 
because of severe abdominal pain, which can be constant, disabling and difficult to treat. Chronic pancreatic pain can prevent the patient from maintaining gainful employment.

The medical treatment of pain in patients with chronic pancreatitis is frequently unsatisfactory and is often complicated by narcotic addiction. This is especially true in patients with a history of dependence on alcohol and drugs. There is no clear treatment approach for chronic pancreatic pain, nor is there presently a standard of care.

The safety and efficacy of endoscopic retrograde cholangiopancreatography and sphincterotomy in patients with acute gallstone pancreatitis are widely recognized, and the indications for endoscopic therapy in pancreatic disorders have been expanded. This article briefly describes endoscopic therapy for patients with chronic pancreatitis and why it should be regarded with conservative optimism.

It has been postulated that stones and strictures lead to hypertension in the main pancreatic duct, which leads to tissue ischemia and pancreatic pain. Endoscopic stenting and stone extraction would then alleviate symptoms by reducing pancreatic ductal pressure.

\section{DRAINAGE OF THE MAIN PANCREATIC DUCT}

Endoscopic therapy, such as stone extraction and stenting of the main pancreatic duct with or without dilation, is usually performed in certain patients with chronic pancreatitis in an attempt to improve ductal drainage. It is offered as an alternative to surgery. Data from over 300 patients who have undergone pancreatic duct stenting for dominant strictures are summarized in Table 1 . The rate of technical success was $99 \%$, with a mean follow-up interval of approximately three years. Symptomatic improvement was reported in $66 \%$ of patients, the complication rate was roughly $20 \%$ and mortality occurred in $1 \%$ of cases.

It is important to understand that stenting may provide medium term relief of pain associated with strictures of the main pancreatic duct, but is not a definitive long term therapy. Moreover, this procedure can result in complications, including cholangitis, hemobilia and stent migration. Multiple stent changes are generally required over the patient's lifetime, which is a considerable problem for patients with a benign condition. Endoscopic therapy has also been found to be potentially effective in treating the complications of chronic pancreatitis, such as jaundice from biliary strictures and pancreatic pseudocysts.

\section{Key point}

The whole rationale for sphincterotomy and stenting is that it alleviates pain by decreasing pancreatic parenchymal pressure. I contend that this line of reasoning is flawed, given the poor results that are obtained with surgical decompression of the pancreatic duct.

\section{PANCREATIC PSEUDOCYSTS}

A pancreatic pseudocyst is defined as a maturing collection of pancreatic secretions that are encased by reactive granulation tissue, which occurs in or around the pancreas as a consequence of inflammatory changes or duct leakage. The term 'pseudocyst' emphasizes the fact the process is not related to neoplasia. Necrosis of peripancreatic tissue frequently produces a phlegmon, which subsequently liquefies and organizes. The resulting fluid collection may or may not communicate with the pancreatic duct. Alternatively, a pseudocyst may result from parenchymal necrosis, which can lead to complete duct disruption and gross leakage of pancreatic juice. Pseudocysts occur after approximately $10 \%$ of attacks of acute pancreatitis.

Patients with chronic pancreatitis, most often due to alcohol abuse, can develop pseudocysts after acute exacerbations of pancreatitis or from progressive ductal obstruction. Such obstruction can be due to either ductal stricturing or the formation of intraductal stones, which in turn is due to protein plugs.

The clinical problems induced by pancreatic pseudocysts are determined by the mechanisms, location and extent of fluid collections. Complications include duodenal or biliary obstruction, vascular occlusion, fistula formation, spontaneous infection with abscess, weakening of vascular walls (resulting in pseudoaneurysms) and rupture into the peritoneal cavity.

Endoscopic treatment for chronic pancreatitis is an alternative to either surgical internal drainage or radiologically guided external drainage. Table 2 shows the results of endoscopic therapy for over 300 patients with pancreatic

TABLE 1

Pancreatic duct stenting for dominant strictures

\begin{tabular}{|c|c|c|c|c|c|c|}
\hline $\begin{array}{l}\text { Author } \\
\text { (year and } \\
\text { reference) }\end{array}$ & $\begin{array}{l}\text { Attempted } \\
\text { patents (n) }\end{array}$ & $\begin{array}{c}\text { Technical } \\
\text { success* }^{*}(n)\end{array}$ & $\begin{array}{c}\text { Mean } \\
\text { follow-up } \\
\text { (months) }\end{array}$ & $\begin{array}{c}\text { Improved } \\
\text { patients }^{\S}(n)\end{array}$ & $\begin{array}{c}\text { Major } \\
\text { complications (n) }\end{array}$ & Deaths (n) \\
\hline McCarthy et al, 1988 (2) & 5 & 5 & 14 & 4 & $2^{\dagger}$ & 0 \\
\hline Grimm et al, 1989 (3) & 63 & 55 & 19 & $31^{\dagger}$ & $20^{\dagger}$ & 1 \\
\hline Cremer et al, 1991 (4) & 76 & 75 & 37 & 41 & 12 & 1 \\
\hline Kozarek et al, 1994 (5) & NA & 17 & 8 & 13 & 3 & 0 \\
\hline Binmoeller et al, 1995 (6) & 93 & 84 & 39 & 61 & 6 & 0 \\
\hline Ponchon et al, 1995 (7) & 28 & 23 & 26 & 12 & 10 & 0 \\
\hline Smits et al, 1995 (8) & 51 & 49 & 34 & 40 & 8 & 0 \\
\hline Total & $311^{\ddagger}$ & $99 \%$ & $34^{\dagger}$ & $66 \%$ & $19 \%^{\dagger}$ & $1 \%$ \\
\hline
\end{tabular}

${ }^{*}$ Refers to the number of patients for whom stenting was successful; ${ }^{\dagger}$ Estimate; ${ }^{\ddagger}$ Does not include the study in which the number of patients attempted is not available; §Refers to the percentage of patients with technical success who enjoyed clinical benefit. NA Not available 
TABLE 2

Results of decompression of pancreatic pseudocysts according to method

\begin{tabular}{|c|c|c|c|c|c|c|}
\hline $\begin{array}{l}\text { Author } \\
\text { (year and } \\
\text { reference) }\end{array}$ & $\begin{array}{c}\text { Technical } \\
\text { success (n) }\end{array}$ & $\begin{array}{c}\text { Trans- } \\
\text { papillary (n) }\end{array}$ & $\begin{array}{c}\text { Cysto- } \\
\text { gastrostomy (n) }\end{array}$ & $\begin{array}{l}\text { Cysto- } \\
\text { duodenostomy (n) }\end{array}$ & $\begin{array}{c}\text { Major } \\
\text { complications (n) }\end{array}$ & Deaths (n) \\
\hline Grimm et al, 1989 (3) & $14 / 16$ & 5 & 1 & 8 & 5 & 1 \\
\hline Cremer et al, 1989 (9) & $32 / 33$ & 0 & 11 & 21 & 3 & 0 \\
\hline Kozarek et al, 1991 (10) & $12 / 14$ & 12 & 0 & 0 & 5 & 0 \\
\hline Binmoeller et al, 1995 (11) & $47 / 53$ & 31 & 6 & 10 & 6 & 0 \\
\hline Smits et al, 1995 (12) & $31 / 37$ & 16 & 8 & 7 & 6 & 0 \\
\hline Barthet et al, 1995 (13) & $58 / 67$ & 26 & 1 & 31 & 9 & 1 \\
\hline Catalano et al, 1995 (14) & $17 / 21$ & 17 & 0 & 9 & 1 & 0 \\
\hline Howell et al, 1998 (15) & $100 / 108$ & 37 & 38 & 25 & 25 & 0 \\
\hline \multirow[t]{2}{*}{ Total } & $311 / 349$ & 144 & 65 & 102 & 66 & 2 \\
\hline & $(89 \%)$ & $(46 \%)$ & $(4 \%)$ & $(33 \%)$ & $(17 \%)$ & $(1 \%)$ \\
\hline
\end{tabular}

pseudocysts. The success rates with transpapillary, cystogastrostomy and cystoduodenostomy approaches were $46 \%$, $21 \%$ and $33 \%$, respectively. Complication rates were as high as $17 \%$ (most of these involved bleeding), and $1 \%$ of patients died. It is important to appreciate that pseudocysts should be considered for drainage only if they are symptomatic, are causing complications or are enlarging.

These preliminary reports are interesting, but there have been no randomized comparative studies to date of different treatment modalities for pseudocysts. Most centres use the technique with which they have the most experience.

In conclusion, endoscopic therapy is a nonsurgical approach to the management of chronic pancreatitis. This new and exciting technology has shown some promising results in several case series. It is my opinion that it should

\section{REFERENCES}

1. Steer ML, Waxman I, Freedman S. Chronic pancreatitis. N Eng J Med 1995;332:1482-90.

1. McCarthy J, Geenen JE, Hogan WJ. Preliminary experience with endoscopic stent placement in benign pancreatic diseases. Gastrointest Endosc 1988;34:16-8.

2. Grimm H, Meyer WH, Nam VC, Soehendra N. New modalities for treating chronic pancreatitis. Endoscopy 1989;21:70-4.

3. Cremer M, Deviere J, Delhaye M, Baize M, Vandermeeren A. Stenting in severe chronic pancreatitis: Results of medium-term follow-up in seventy-six patients. Endoscopy 1991;23:171-6.

4. Kozarek RA, Ball TJ, Patterson DJ, Brandabur JJ, Traverso LW, Raltz S. Endoscopic pancreatic duct sphincterotomy: Indications, technique, and analysis of results. Gastrointest Endosc 1994;40:592-8.

5. Binmoeller KF, Jue P, Seifert H, Nam WC, Izbicki J, Soehendra N. Endoscopic pancreatic stent drainage in chronic pancreatitis and a dominant stricture: Long-term results. Endoscopy 1995;27:638-44.

6. Ponchon T, Bory RM, Hedelius F, et al. Endoscopic stenting for pain relief in chronic pancreatitis: results of a standardized protocol. Gastrointest Endosc 1995;42:452-6.

7. Smits ME, Badiga SM, Rauws EA, Tytgat GN, Huibregtse K. Longterm results of pancreatic stents in chronic pancreatitis. Gastrointest Endosc 1995;42:461-7. be regarded with conservative optimism. Unfortunately, there have been no controlled comparison studies of endoscopic versus surgical or radiological intervention. The position statement of the American Gastroenterological Association is accurate when it states that no guidelines have yet been published that validate most endoscopic modalities. This would require blinded, prospective, controlled trials that include assessment of abdominal pain and quality of life measures.

\section{Key point}

The evidence supporting the use of endoscopic therapy for pain in chronic pancreatitis is preliminary and largely confined to short term focus observations. These procedures require further evaluation in clinical trials.

8. Cremer M, Deviere J, Engelholm L. Endoscopic management of cysts and pseudocysts in chronic pancreatitis: Long-term follow-up after 7 years of experience. Gastrointest Endosc 1989;35:1-9.

9. Kozarek RA, Ball TJ, Patterson DJ, Freeny PC, Ryan JA, Traverso LW. Endoscopic transpapillary therapy for disrupted pancreatic duct and peripancreatic fluid collections. Gastroenterology 1991;100:1362-70.

10. Binmoeller KF, Seifert H, Walter A, Soehendra N. Transpapillary and transmural drainage of pancreatic pseudocysts. Gastrointest Endosc 1995;42:219-24.

11. Smits ME, Rauws EA, Tytgat GN, Huibregtse K. The efficacy of endoscopic treatment of pancreatic pseudocysts. Gastrointest Endosc 1995;42:202-7.

12. Barthet M, Bugallo M, Moreira LS, Bastid C, Sastre B, Sahel J. Management of cysts and pseudocysts complicating chronic pancreatitis. A retrospective study of 143 patients. Gastroenterol Clin Biol 1993;17:270-6.

13. Catalano MF, Geenen JE, Schmalz MJ, Johnson GK, Dean RS, Hogan WJ. Treatment of pancreatic pseudocysts with ductal communication by transpapillary pancreatic duct endoprosthesis. Gastrointest Endosc 1995;42:214-8.

14. Howell DA, Elton E, Parsons WG. Endoscopic management of pseudocysts of the pancreas. Gastrointest Endosc Clin N Am 1998;8:143-62. 


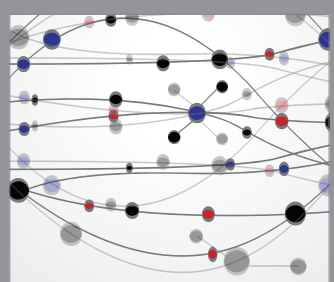

The Scientific World Journal
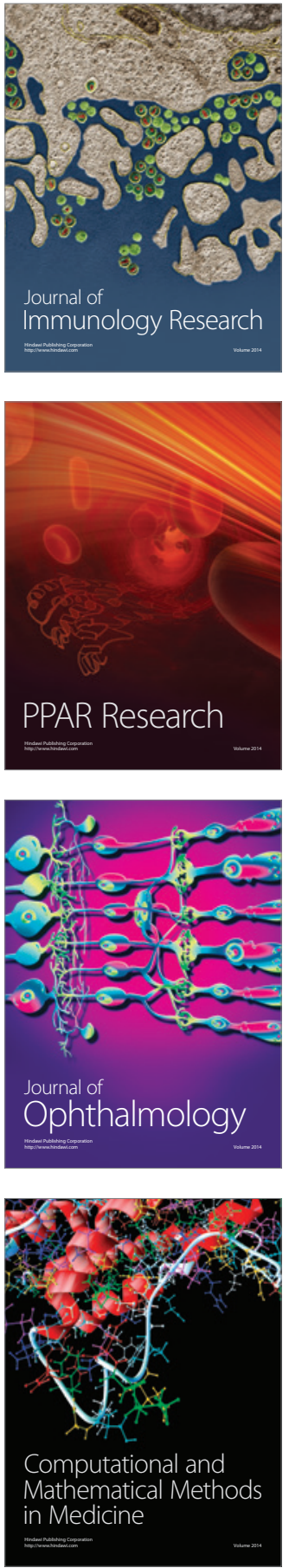

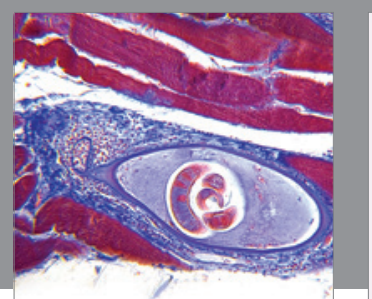

Gastroenterology Research and Practice

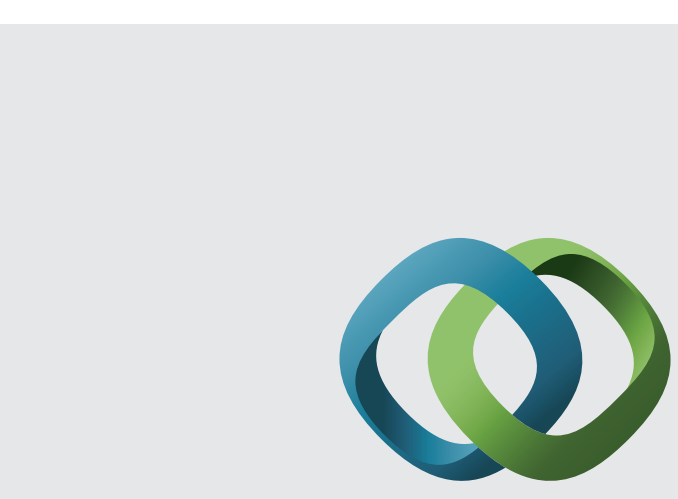

\section{Hindawi}

Submit your manuscripts at

http://www.hindawi.com
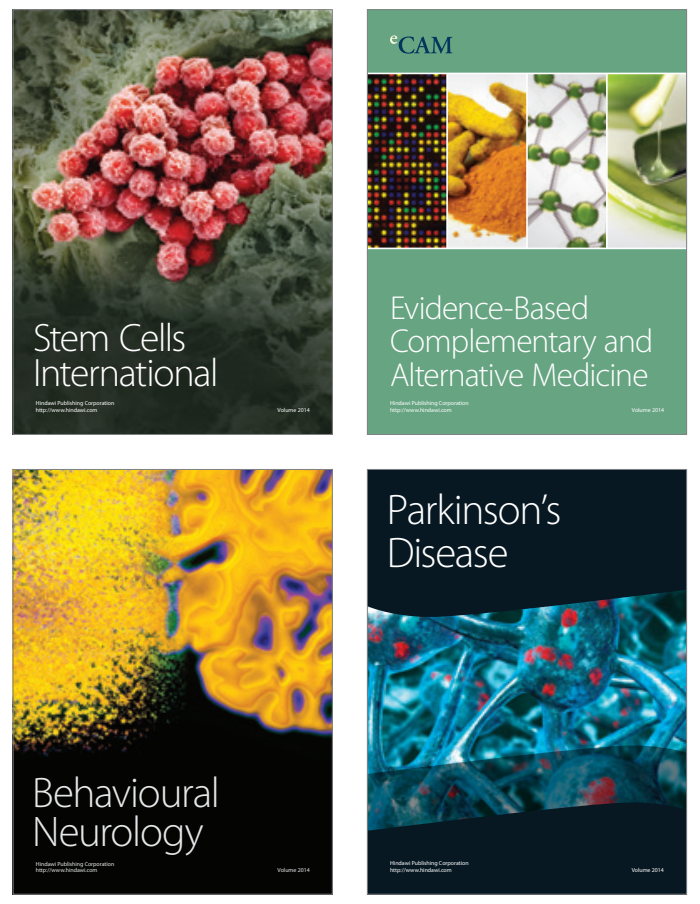
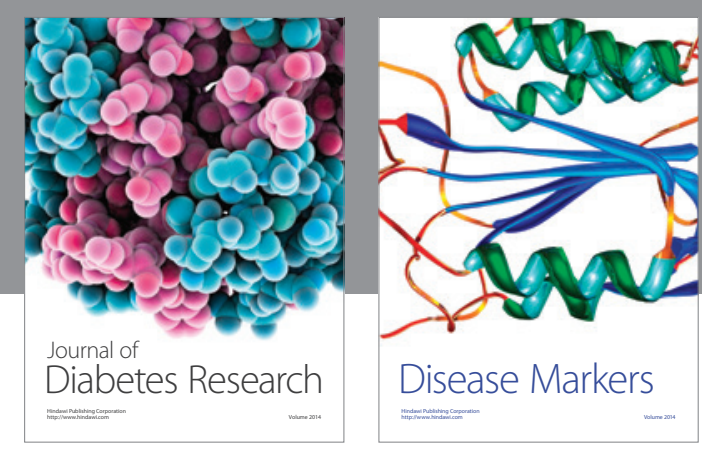

Disease Markers
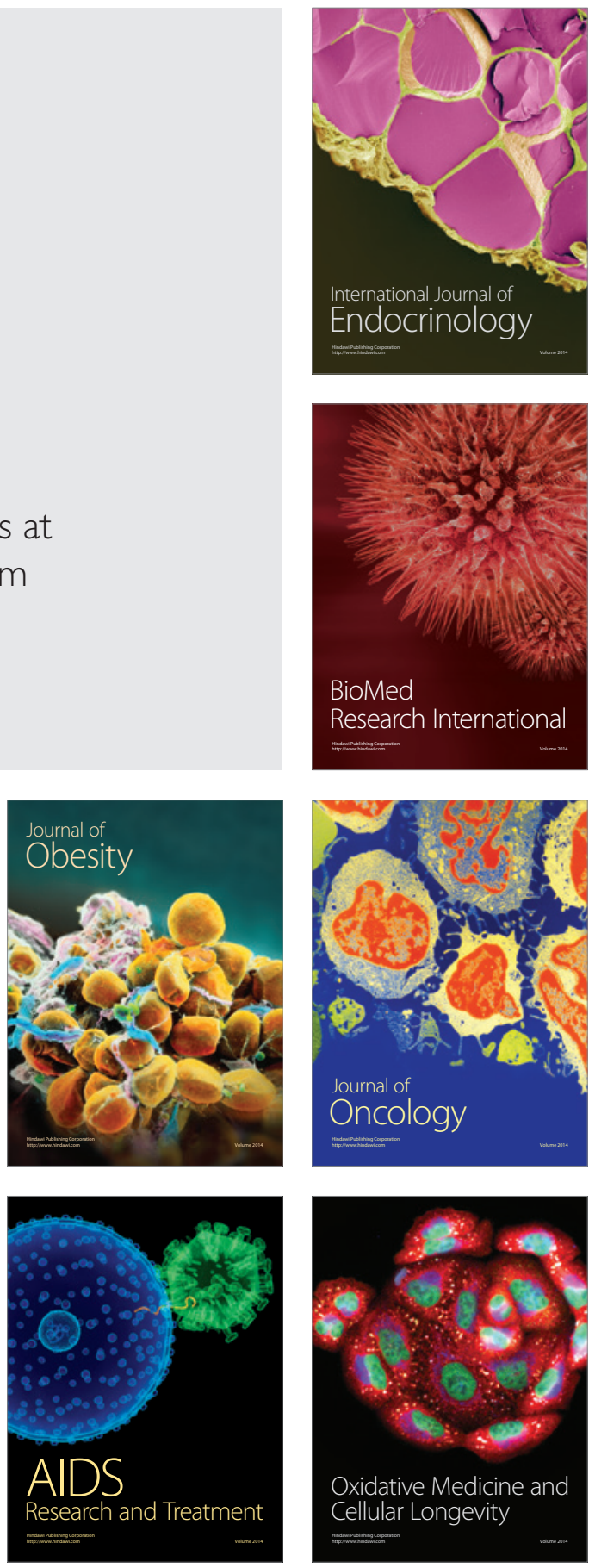